\title{
TEMPO, LUGAR E INTERCULTURALIDADE NA PERSPECTIVA DOS ESTUDANTES INDÍGENAS DO CURSO DE EDUCAÇÃO INTERCULTURAL - UFG
}

ORDÁLIA CRISTINA GONÇALVES ARAÚJO²
$U F G / U E G$

TAMIRIS MAIA GONÇALVES PEREIRA ${ }^{3}$

$U F G$

\begin{abstract}
RESUMO: Este artigo tem como objetivo básico discutir, a partir da experiência docente no Curso de Educação Intercultural - UFG, a pretensa universalização do conceito de tempo das sociedades ocidentalizadas. Debates em sala de aula, trabalhos individuais e em grupo para registros de narrativas orais e escritas e confecção de mapas existenciais contribuíram para corroborar com o pressuposto de que determinadas culturas, dentre elas as indígenas, experimentam o "tempo" desde o lugar em que estão inseridas, prescindindo da perspectiva linear, cronológica e processual do tempo. Toda a trajetória pedagógica das aulas e a reflexão dos resultados tiveram como aporte teórico as discussões em torno do enfoque enactivo (ESCOBAR, 2003, 2005; MALDONADO-TORRES, 2010; NAZARENO; CARDOSO, 2013; SANTOS, 2006).
\end{abstract}

PALAVRAS-CHAVE: tempo; lugar; interculturalidade; educação intercultural.

ABSTRACT: This article aims to discuss, from the teaching experience in the Course of Intercultural Education - UFG, the supposed universalization of the concept of time of westernized societies. Classroom discussions, individual and group work for records of oral and written narratives, and the making of existential maps have contributed to the assumption that certain cultures, including Indigenous cultures, experience "time" from where they are inserted, regardless of a linear, chronological and processual perspective. All the pedagogical trajectory

\footnotetext{
${ }^{1}$ Professor Associado I da Universidade Federal de Goiás no Programa de Pós-graduação em História e no Curso de Educação Intercultural para a formação de Professores Indígenas da UFG. Coordenador Institucional do Programa Institucional de Bolsas de Iniciação à Docência - Pibid/Diversidade/Capes da UFG e Coordenador do Grupo de Pesquisa História indígena e História ambiental: interculturalidade crítica e decolonialidade, vinculado ao Diretório de Grupos de Pesquisa do CNPq. E-mail: eliasna@ hotmail.com ${ }^{2}$ Doutoranda do Programa de Pós-Graduação de História da Universidade Federal de Goiás na Área de Concentração: Cultura, Fronteiras e Identidades e Linha de Pesquisa: Fronteiras, Interculturalidades e Ensino de História. Professora na Universidade Estadual de Goiás. E-mail: ordalia_c@ hotmail.com ${ }^{3}$ Doutoranda do Programa de Pós-Graduação de História da Universidade Federal de Goiás na Área de Concentração: Cultura, Fronteiras e Identidades e Linha de Pesquisa: Fronteiras, Interculturalidades e Ensino de História. E-mail: tamirismaia_19@hotmail.com
} 
of the classes and the reflection upon the results had as a theoretical contribution the discussions around the enactive focus (ESCOBAR, 2003, 2005; MALDONADO-TORRES, 2010; NAZARENO; CARDOSO, 2013; SANTOS, 2006).

KEYWORDS: time; place; interculturality; intercultural education.

\section{Apresentação}

"Tempo, lugar e interculturalidade" constitui-se num espaço pedagógico do Curso de Educação Intercultural (CEII) da Universidade Federal de Goiás para o debate dos conceitos que nomeiam este tema contextual. ${ }^{4}$ Planejado para ser desenvolvido durante a segunda etapa de estudos presenciais do curso em $2017,{ }^{5}$ durou uma semana de atividades didático-reflexivas elaboradas com o fim de, por um lado, expor, debater e criticar a noção de tempo pretensamente hegemônica na sociedade ocidental e, por outro, corroborar com o pressuposto de que determinados povos indígenas prescindem dessa noção, tal como experimentada nas sociedades ocidentalizadas.

No decorrer do tema, noções outras de tempo foram sistematizadas e expostas a partir da cosmovisão dos onze povos indígenas representados em sala de aula, tornando possível um posicionamento crítico dos participantes a partir de suas próprias experiências e conhecimentos vinculados à maneira como vivenciam o tempo e o lugar. Nesse sentido, pretendemos expor os resultados do debate efetivado no decorrer do tema, dialogando com as discussões conceituais e teóricas imbricadas nesta proposta.

Discutir e apresentar noções outras de temporalidades subjacentes aos povos indígenas participantes do CEIl da UFG ${ }^{6}$ insere-se no debate

\footnotetext{
${ }^{4}$ Os temas contextuais substituem as disciplinas no Projeto Pedagógico do Curso de Educação Intercultural Indígena, pautado pelos princípios da transdisciplinaridade e da interculturalidade crítica no sentido de ir além, ultrapassar as pedagogias ocidentais focadas na divisão disciplinar do conhecimento. Os temas contextuais sustentam a base epistêmica do curso ao propor uma relação de complementariedade entre conhecimentos ocidentais e saberes indígenas. Pretende romper com a concepção hierárquica e fragmentária do conhecimento disciplinar em benefício de um saber contextualizado a fim de superar as metodologias ocidentais ao problematizar os saberes e conhecimentos locais, subalternizados pela episteme ocidental, com vistas à emancipação intelectual dos atores envolvidos no processo político-pedagógico por meio da pesquisa e da autoria de textos próprios. Para uma discussão mais aprofundada sobre a concepção de tema contextual ver NAZARENO, Elias e ARAÚJO, Ordália C.G. Reflexões em torno do tema contextual "Etnicidade e diversidade cultural". Revista Articulando e construindo saberes. Vol. 2, n.1, 2017. ${ }^{5} \mathrm{O}$ tema contextual ocorreu entre 31 jul. e 04 ago. 2017 nas dependências do Núcleo Takinahaky de Formação Superior Indígena sob a coordenação do prof. dr. Elias Nazareno. Participaram das aulas as turmas de 2014 (catorze estudantes) e 2015 (doze estudantes), totalizando 26 pessoas e onze povos representados (Canela, Guajajara, Javaé, Juruna, Kamayurá, Karajá, Krahô, Tapirapé, Tapuia, Xavante e Xerente) advindos dos estados de Goiás, Maranhão, Mato Grosso e Tocantins.

${ }^{6}$ Criado em 2007, o Curso de Educação Intercultural Indígena atende povos das regiões Araguaia-Tocantins e do Xingu nos estados de Goiás, Maranhão, Mato Grosso e Tocantins, envolvendo os Apinajé, Canela,
} 
atual proposto pela decolonialidade e pela interculturalidade crítica, no contexto latino-americano, e pelo marco constitucional brasileiro de 1988, ao outorgar aos povos originários a garantia de direitos que incluem o reconhecimento da diversidade cultural e da soberania indígenas das terras tradicionalmente ocupadas por eles (Art. 231 e 232), uma educação própria e diferenciada (Art. 210 , parágrafo 2 ) e a proteção às suas manifestações culturais (Art. 215, parágrafo 1).

Decolonialidade e interculturalidade crítica estão intimamente imbricadas desde o momento de instauração do projeto de poder colonial nas Américas:

\begin{abstract}
A interculturalidade crítica, entendida como processo social, político e epistêmico, pode ser considerada, portanto, como sinônimo da decolonialidade, pois, mesmo tendo em conta as relações assimétricas estabelecidas pelo colonizador em termos políticos, sociais e epistêmicos, não há como negar a influência recíproca exercida por parte daqueles que foram historicamente subalternizados. Nesse sentido, a decolonialidade instala-se no mesmo momento em que se instala a colonialidade do poder. Os povos indígenas que permanecem vivos, com seus conhecimentos e suas línguas, são uma prova viva da decolonialidade como processo de resistência e afirmação identitária (NAZARENO, 2017, p. 46).
\end{abstract}

Desta feita, a discussão proposta pelo artigo contribui para o objetivo mais amplo do curso citado, ou seja, a formação de professores indígenas para atuarem nas escolas indígenas de suas aldeias desde um posicionamento decolonial e intercultural de resistência epistêmica e ontológica (NAZARENO, 2016, p. 4), visando ainda a divulgação de saberes e conhecimentos não ocidentais nos meios acadêmicos brasileiros.

A proposta constitui-se em desocultar e dar abertura aos saberes que foram subalternizados e silenciados ao longo da história dos contatos entre indígenas e não indígenas no Brasil, partindo da diferença colonial, o lócus de emergência da colonialidade do poder (MIGNOLO, 2003, p. 10). Categoria esta que referencia uma relação de poder que se caracteriza não apenas pela dominação coercitiva, fundada na suposta superioridade étnica e epistêmica dos europeus sobre os povos nativos, visando sua destruição física e a transformação de suas formas imemoriais de conhecer o mundo e a si mesmos, a fim de adotar o universo cognitivo do colonizador, mas também na sedução provocada pela cultura europeia, a partir do imaginário de la blancura (QUIJANO, 2000; CASTROGÓMEZ, 2005).

Gavião, Guajajara, Javaé, Juruna, Kalapalo, Kamaiurá, Karajá, Krahô, Krikati, Kuikuro, Mehinako, Tapirapé, Tapuia, Timbira, Xakriabá, Xambioá, Xavante, Xerente e Waura (NAZARENO, 2016, p. 7). 
Ser "branco", nesse imaginário, não tem a ver com caracteres fenotípicos observáveis em uma pessoa, como a cor da pele ou o tipo de cabelo, e sim com um imaginário cultural forjado por crenças religiosas, tipos de vestimenta, modos de comportamento e, principalmente, modos de produzir e transmitir conhecimentos (CASTRO-GOMEZ, 2005, p. 59-60) cristalizados na base epistêmica colonial erigida sob o fundamento do dualismo ontológico responsável pela dicotomização entre corpo e mente, cultura e natureza, doxa e episteme, dentre outras dicotomias. Por isto, trata-se de uma colonialidade que ultrapassa as relações de poder e o contexto histórico da colonização europeia, ao constituir-se numa estrutura complexa de níveis entrelaçados, atravessada por atividades e controles específicos como a colonialidade do saber, do ser, do ver, do fazer, do pensar e do ouvir, dentre outras (MIGNOLO, 2010; NAZARENO, 2017).

A subalternização e ocultação de saberes e conhecimentos oriundos dos povos originários, levadas a cabo pelo projeto colonial ao longo da história dos contatos entre indígenas e não indígenas, se fizeram perceptíveis na organização cosmológica de inúmeros povos submergidos e submetidos à colonialidade do poder, de especial modo, em relação ao uso da noção ocidental de tempo, uma categoria que não exprime a experiência humana, mas advém de uma construção epistêmica forjada desde o século XVI sob a filosofia judaico-cristã. Secularizada por Kant no século XVIII, à noção de tempo coube a categorização dos povos situados fora da Europa como bárbaros e atrasados. Os europeus, localizados no ápice da trajetória linear do tempo, eram os civilizados em contraposição aos outros povos existentes no mundo (MIGNOLO, 2011).

Era a negação da coetaneidade entre o modelo de civilização do europeu e seu "outro" e, também, o início do surgimento da diferença colonial, como espaço de imposição, necessidade, apropriação e resistência (NAZARENO, 2016). Um espaço que se configura atualmente no CEIl por meio da emergência e desocultação de saberes e conhecimentos postos em circulação pelo projeto e atitude decolonial concretizado por docentes e pesquisadores a ele vinculados com a finalidade de dialogar com a matriz de conhecimento monotópica e monocultural vigente em nossa sociedade.

Um projeto e atitude que se desdobra em uma produção acadêmica e bibliográfica resultante de pesquisas gestadas nas demandas postas pela própria comunidade indígena a partir da postura investigativa e da retomada de saberes efetivada por cada estudante indígena em sua aldeia no decorrer no curso. Pautada pela pluridiversidade cultural, os resultados de tais pesquisas podem ser visualizados nos inúmeros materiais didáticos produzidos e colocados em uso nas escolas indígenas ${ }^{7}$ cuja finalidade não tem um fim em si mesmo, mas comunica a

${ }^{7}$ Parte desses materiais pode ser encontrada nos dez volumes da Coleção Documentação de Saberes Indígenas. ed. Goiânia: Gráfica UFG, 2017. 
necessidade de compartilhar narrativas outras que demonstram a pluridiversidade epistêmica dos conhecimentos e saberes existentes no Brasil, pois

a história da colonização dos povos indígenas no Brasil, e, porque não dizer, de quase toda a América Latina, deve ser urgentemente revista e reconstruída. Grande parte dos relatos historiográficos que possuímos no Brasil e no mundo acerca da história do contato entre o europeu e os indígenas brasileiros, com raras exceções, contam apenas as versões ocidentais e dificilmente são encontradas narrativas historiográficas elaboradas a partir dos próprios indígenas, relacionadas ao que representou para eles esse contato (NAZARENO, 2016, p. 3).

Participar desse processo de revisão e reconstrução da história do Brasil e, no limite, da América Latina, significa compreender a urgência em se construir macronarrativas que se constituam como lugares de emergência e implementação de "um outro pensamento", de uma nova maneira de pensar, de um caminhar em direção "a uma outra lógica" em que se mudam "os termos, e não apenas o contexto da conversação" (MICNOLO, 2003, p. 106). Trata-se de pensar em pedagogias fundadas nas memórias coletivas dos povos originários, pois são nessas memórias de longa duração que o pedagógico e o decolonial se articulam como projeto e atitude política, social, cultural e existencial, no qual se constitui práticas de aprendizagem, desaprendizagem, reaprendizagem, reflexão e ação com vistas a questionar e desafiar a racionalidade e o poder colonial (WALSH, 2013).

A reescrita da história dos contatos pelo viés da decolonialidade e da interculturalidade crítica considera os povos indígenas como copartícipes dela, ao contrário da escrita historiográfica vigente que, "quando muito, [os considera] como coadjuvantes de uma história que, ao prescindir deles, não existe de fato" (NAZARENO, 2016, p. 3).

Propor a discussão a partir do uso da noção de "tempo" para os povos originários participantes do CEll constitui-se, pois, em uma contribuição basilar para a revisão de um dos pressupostos caros à episteme ocidental. Muitos desses povos sequer atribuem em sua língua materna uma palavra que traduziria o termo "tempo". Embora não seja possível afirmar que eles prescindam do mesmo, é fato que em suas vivências cosmológicas é perceptível a indissociabilidade entre tempo, espaço, corpo e natureza. ${ }^{8}$ A ocorrência de categorias que remetem ao tempo nas narrativas indígenas como datas, dias, semanas, meses, anos,

\footnotetext{
${ }^{8}$ Norbert Elias em Sobre o tempo faz alusão ao povo indígena norte americano Sioux que tão pouco possui uma palavra para classificar o que se entende por tempo. "Que acharia o senhor", perguntou ele, "de um povo que não dispõe de nenhuma palavra para expressar tempo? Minha gente não tem nenhuma palavra que signifique 'atrasado ou esperar" (1998, p. 111).
} 
períodos, estações do ano, dentre outras, apontam para o "processo linguístico, político e social de imposição, apropriação e utilização intercultural dessas categorias", cuja frequência "revela o caráter dinâmico e a necessidade de atualização ontológica, recurso vital para a permanência desses povos" (NAZARENO, 2016, p. 19).

Assim é que, a partir de narrativas e de mapas existenciais construídos por estudantes indígenas durante o desenvolvimento do tema contextual Tempo, lugar e interculturalidade dentro da proposta de atividades do tema, pretendemos corroborar para o fato de que os povos indígenas mantêm com o tempo uma relação de inseparabilidade entre o lugar no qual existem ontologicamente, estruturando suas narrativas desde e a partir desse lugar. Daí a importância do enfoque enactivo para nossa discussão (ESCOBAR 2005; 2013).

Opondo-se à tradição racionalista pautada por diversos dualismos, entre eles o dualismo corpo e mente, para as ciências cognitivas, a enacción (ação corporizada no mundo) fundamenta a cognição, já que o conhecimento depende das interações entre nosso corpo, nossa linguagem e nossa história social ocorridas em um mundo não fixo e não preexistente, mas plasmado a partir dos atos efetuados por nós como conhecedores. Destarte,

el conocimiento es el resultado de una interpretación que emerge de nuestra capacidad de comprensión. Esta capacidad está arraigada en la estructura de nuestra corporización biológica, pero se vive y se experimenta dentro de un dominio de acción consensual e historia cultural. Ella nos permite dar sentido a nuestro mundo; o, en un lenguaje más fenomenológico, constituye las estructuras por las cuales existimos a la manera de "tener un mundo" (VARELA et al, 1992, p. 177, grifos no original) ${ }^{9}$.

O enfoque enactivo compartilha do aporte das epistemologias ecológicas nas quais o conhecer "é fundamentalmente uma habilidade que adquirimos na relação com outros organismos e seres que habitam o mesmo mundo, e não uma prerrogativa humana que se processaria no espaço restrito da mente como uma operação racional. Torna-se, assim, impossível dissociar a mente do corpo, a cultura da natureza, o conhecimento da experiência" (STEIL; CARVALHO, 2014, p. 164).

Desde nossas experiências e atuação em meio aos povos indígenas da região Araguaia-Tocantins e Xingu, é perceptível que para o indígena não há separação entre o que consideramos conhecimento teórico e conhecimento prático. Os saberes indígenas constituem-se da confluência

\footnotetext{
9 "O conhecimento é o resultado de uma interpretação que emerge da nossa capacidade de compreensão. Esta capacidade está arraigada na estrutura de nossa corporização biológica, porém se vive e se experimenta dentro de um domínio de ação consensual e história cultural. Ela nos permite dar sentido ao nosso mundo; ou, em uma linguagem mais fenomenológica, constitui as estruturas pelas quais existimos à maneira de "ter um mundo" (tradução dos autores).
} 
entre a teoria e o fazer, pois acontecem de forma simultânea dada a sua complexidade cognitiva. Para a episteme ocidental, o conhecimento está separado do corpo. Todavia, no enfoque enactivo, o conhecimento depende do corpo, por isto que, para os indígenas, o conhecimento engloba o engajamento na natureza, visto ser este seu espaço de experiências e constituição identitária.

A seguir, trataremos dos aspectos metodológicos adotados ao longo do tema contextual, no qual a fala dos indígenas é considerada como fundamental para que se possam estabelecer relações interculturais e verdadeiramente interepistêmicas.

\section{Narrativas}

Inicialmente organizamos uma proposta para que os estudantes narrassem - primeiro, a partir da oralidade e, posteriormente, da escrita - uma experiência vivida, objetivando delinear as maneiras específicas com que eles vivenciam o tempo e o lugar. A opção por narrar determinada experiência deveria ser feita por cada estudante para permitir a maior liberdade possível, ainda que limitada pelo ambiente escolar.

Em virtude do predomínio da oralidade entre os indígenas, a atividade solicitada deveria ser feita na língua materna e posteriormente escrita na língua portuguesa. Partimos do pressuposto de que narrando a partir da linguagem cotidiana, termos que remetem ao tempo e ao lugar (ou noções similares) nas línguas maternas seriam mais espontaneamente utilizados e, desta maneira, mais facilmente detectados. Assim, as narrativas constituíram-se essenciais na identificação do uso destes tipos de advérbios tanto na oralidade como na escrita dos estudantes, com o fim de corroborar com o pressuposto de que determinados povos indígenas prescindem do conceito de tempo, tal como experimentado nas sociedades ocidentais.

Após a realização desta atividade, percebemos que as narrativas produzidas pelos estudantes compunham basicamente dois tipos de categorias. De um lado, alocamos aquelas estruturadas em torno de marcos cronológicos, caracterizadas pelo predomínio das trajetórias escolares de seus autores e autoras, tendo em perspectiva o desenvolvimento cognitivo com vistas às estratégias de negociação com a sociedade envolvente. Por outro lado, reunimos aquelas que relataram experiências para além do ambiente institucionalizado da escola abrangendo aspectos cosmológicos da história do povo narrado.

De maneira geral, as narrativas que remontam ao percurso escolar seguem um padrão de escrita ao retratar a vida do estudante numa sequência linear com marcos que sinalizam o início e o fim de um percurso acadêmico: início da escolarização (alfabetização) e finalização da educação básica no ensino médio, em busca de algo melhor (Samanta Javaé, jul. 2017). O percurso escolar é delineado em torno da idade 
cronológica da estudante, dos períodos e séries que cursou na educação básica e do tempo gasto para realizar cada uma das etapas narradas. $O$ lugar (cidade, escola, aldeia) aparece concatenado ao ambiente de realização de determinada fase da trajetória escolar, submetido, portanto, aos aspectos temporais.

A intitulação de algumas narrativas pelos próprios estudantes aponta para a preponderância da cronologia, da linearidade e das fases escolares como tema central.

- Experiência vivida com a formação das palavras (Marlonlrepa i Tapirapé)

- O resgate e fortalecimento da cultura Krahô na escola (Leonardo Tupen Krahô)

- Minha passagem de estudo da aldeia para a cidade (Higino Tsitomowe Paramei'wa)

- Minha história (Samanta Javaé Araújo)

Estas são permeadas de experiências dramáticas, pois muitas delas ocorreram em contextos não indígenas nos quais a fluência na língua portuguesa constituía-se em um limite para a plena integração do estudante no ambiente escolar. Porém, era necessário superar tais dificuldades, enfrentando, muitas vezes, intempéries durante o trajeto aldeia-escola, em meios de transportes inadequados ou atitudes preconceituosas de professores e colegas de sala, visto que a apreensão dos conhecimentos escolarizados revertia-se numa estratégia de manutenção e sobrevivência física, cultural e, sobretudo, territorial (Eliênia Caetano Martins, jul. 2017).

Em muitos casos, a escola é lugar da cultura não indígena, portanto, a experiência de vida com ênfase na trajetória de escolarização é cronologizada, marcada por datas, períodos/séries, começo e fim, de linearidade e progresso (desenvolvimento), situação que corrobora com os processos interculturais efetivados pelos indígenas. A partir das tentativas de imposição de critérios de organização social e cultural do tempo por meio da imposição de um modelo linguístico e educacional, os indígenas passaram por processos de atualização ontológica - os processos interculturais - possibilitados pela resistência epistêmica, característica que Ihes é peculiar. Pensar a partir da escola ocidental significa, para muitos estudantes, estabelecer uma trajetória linear que se inicia com o ingresso na escola ou quando começa a alfabetização na língua portuguesa e finaliza, parcialmente, com o término de determinada fase educacional (ensino médio).

Finalizar o ensino médio, para muitos, não significa o encerramento da fase de aprendizado. Uma nova etapa de conhecimentos se inicia com o ingresso na educação superior. Estar no Curso de Educação Intercultural da UFG é visto como um espaço para fortalecer a cultura de cada povo, buscando estratégias de revitalização cultural, no sentido amplo do termo: aprofundar conhecimentos concernentes às ervas medicinais, 
língua materna, rituais, festas, artesanato, pinturas. Estratégias que perpassam pelo ambiente escolar, nesse novo contexto, mas não determinado por ele e sim por toda a comunidade indígena, orientados pelos sábios e anciãos, os detentores dos conhecimentos ancestrais, conforme exemplificado pela história de luta dos Tapirapé em busca de seus territórios, cujo desdobramento foi a demanda pela escola indígena intercultural.

As experiências e aprendizados do Curso de Educação Intercultural Indígena (CEII) são internalizados e vivenciados no contexto da aldeia de maneira intercultural. Leonardo Tupen Krahô (jul. 2017) narrou sua atuação como docente na Escola Estadual Indígena 19 de Abril:

Dentro de uma semana é lecionado normalmente a aula com as disciplinas dentro de 45 minutos.

E em outra semana é Tema Contextual, onde trabalhamos durante uma semana apenas com 0 conhecimento tradicional, músicas, resguardos, festas ou uma história. Nós problematizamos o tema escolhido e pesquisamos com os nossos anciões e sábios da aldeia, produzimos cartazes, relatórios e desenhamos ou até fazemos a cena e dramatização (simulação) de um tema pesquisado. A apresentação do tema contextual é na sexta-feira para a comunidade. Por que ensinamos dessa forma? Para que as nossas crianças saibam conhecendo os dois conhecimentos do cupê (não indígenas) e do Mehi, os indígenas Krahô.

Mas importante é preparar a criança o que ela é. Ser uma criança do seu povo, conhecer o seu originário.

A narrativa de Leonardo Krahô aponta para o protagonismo indígena na atualidade. Desde o marco constitucional de 1988 , os povos originários tiveram garantidos seus direitos à educação diferenciada e intercultural pelos Artigos 231 e 232 da Constituição Federal. A criação de cursos superiores de formação de docentes indígenas como o CEll da UFG insere-se nesse contexto contemporâneo das histórias de luta dos povos indígenas no Brasil. Paralelo a isto, está a luta pela retomada de terras encampada por povos como os Xavante desde então, constituindose em outra temática retratada nas narrativas produzidas em sala de aula, conforme a escrita de José de Arimatéia Tserewamriwe Tserenhitomo (jul. 2017):

Eu nasci no dia 16 de abril de 1976, na Aldeia São Marcos, município de Barra do Garças.

Em 1956, nossos ancestrais foram retirados fora de sua terra, denominado povo Xavante de Marãiwatsede (mata fechada perigosa) pela Força Aérea Brasileira (FAB) e foram deslocados para a região de São Marcos onde mora outros Xavante. Entre os retirados está o meu pai. 
Então ele conta história da retirada, quando eu era pequeno. Em 1986 me tornei adolescente e em 1989 participei da cerimônia de furação de orelha e em 1992 saí fora da Aldeia para estudar, sempre pensando na tragédia que aconteceu no ano de 1956. Quando concluí o Ensino Médio, voltei para Aldeia Água Branca, na Terra Indígena Pimentel Barbosa, onde o cacique da aldeia decidiu lutar pela retomada da Terra Marãiwatsede para resgatar, revitalizar o que foi perdido. Em 1995, comecei acompanhar a luta do cacique. Me ofereci, interessei de lutar juntos. Em 1998 saiu a homologação da Terra. Em 2002 acampamos na beira da estrada, esperando a decisão judicial para a entrada do povo Xavante na sua área.

Assim foi a história da retomada, 45 anos de luta, valeu para que as nossas gerações tenham a sua própria terra para reconstruir a vida.

Embora as duas narrativas apresentadas acima aludam ao contexto escolar, a questão preponderante são as demandas dos Krahô e dos Xavante: o fortalecimento identitário e a retomada territorial, respectivamente.

O uso da metodologia do tema contextual como prática pedagógica decolonial na escola indígena krahô evidencia a estratégia política de negociação com a sociedade envolvente. Não é possível prescindir do conhecimento científico ocidental; todavia, os saberes e conhecimentos ancestrais fundamentam a identidade krahô, interligando as gerações passada e presente pelas interações cognitivas possibilitadas pela convivência dos sábios com as crianças. Nessa estratégia, ainda que a perspectiva de futuro apareça como na narrativa de Samanta Javaé e Valdemar Xavante ${ }^{10}$, o essencial é "relatar, resgatar tudo o que estamos esquecendo de nossos antepassados, trazer de volta comida típica tradicional, mestre, cântico, medicina tradicional" (Armando Prefete Kapelikó Canela, jul. 2017).

De maneira ampla, a revitalização cultural perpassa pela retomada da terra. A narrativa de José de Arimatéia aponta para este pressuposto. O lugar, na narrativa, constitui a história, ou melhor, a estrutura narrativa e a identidade dos Xavante. Existe uma cronologia na narrativa para delimitar acontecimentos ocorridos antes mesmo da existência do autor, como a expulsão de seus parentes (incluindo seu pai) do lugar (terra) de origem, no período anterior ao seu nascimento. A identificação com a dramática história de seus ancestrais proporciona o posicionamento político em querer lutar, ao lado de outras lideranças Xavante, pela retomada da terra indígena.

\footnotetext{
10“'A conquista da busca do novo conhecimento é para se usar como arma científica, para que se restam um mundo melhor para os netos e novas gerações em gerações” (Valdemar Xavante, jul. 2017).
} 
À trajetória escolar segue-se a luta pela terra na narrativa que inclui os marcos cronológicos para relatar parcialmente a história dos Xavante da Terra Indígena ( $\mathrm{Tl})$ Marãiwatsédé. Entretanto, a cronologia (o tempo) não é o determinante nessa história, mas sim o espaço como lugar de vivência e experiência cosmológica, visto que a luta ocorre para "resgatar, revitalizar o que foi perdido" (a terra, as histórias, a identidade) e ainda "para que as nossas gerações tenham a sua própria terra para reconstruir a vida". Uma reconstrução pautada pelo diálogo intercultural entre saberes ancestrais e contemporâneos vivenciados na TI Marãiwatsédé.

A escola como espaço de luta e atualização ontológica é perceptível a partir da experiência dos Tapirapé que, na década de 1960, diante da colonização da Amazônia no período militar, viram-se inseridos no contexto de luta pela retomada de seus territórios ancestrais. Numa atitude de resistência epistêmica, eles perceberam a necessidade de conhecer os códigos linguísticos dos não indígenas, principalmente para compreender a opção dada a eles pelo Estado brasileiro: uma porção de terras na llha do Bananal, então estado de Goiás, em troca de seus territórios ancestrais.

Com vistas à compreensão dos códigos escritos em língua portuguesa (ler o mapa e seus símbolos apresentado pelos técnicos do governo com a localização da nova terra) e à negociação pela retomada das terras originárias, os Tapirapé reivindicaram a construção de uma escola intercultural na aldeia Tapi'itãwa (Urubu Branco - Mato Grosso). Esta, após seu estabelecimento, apresentou-se como um espaço de apropriação de saberes não indígenas e como movimento de resistência, negociação e afirmação:

Desde 2007, por influência dos alunos Tapirapé que estão no curso de Licenciatura Intercultural Indígena para a formação de professores indígenas na UFG, as escolas Tapirapé tem vivenciado um processo de aprofundamento da valorização de seus saberes. Assim, há um forte movimento de revitalização da língua Tapirapé, por meio do que eles mesmos chamam de políticas linguísticas. Um exemplo disto é a criação de novas palavras que antes só existiam na língua portuguesa e que agora existem em Tapirapé e estão sendo adotadas no cotidiano da escola e da comunidade. Outro exemplo foi a adoção de medidas estritas em relação ao uso de alimentos na merenda escolar, alimentos por eles chamados de ocidentais, como o açúcar, o sal, o refrigerante e os biscoitos estão sendo substituídos por alimentos tradicionais, como o peixe, a farinha de mandioca e etc. Tal postura corrobora a perspectiva que aponta para a resistência epistêmica deste povo (LIMA; NAZARENO, 2014, p. 22-23). 
No outro conjunto de histórias, advérbios de tempo e lugar perpassam as narrativas, numa aproximação das considerações de Mignolo (2011) ao afirmar que nas sociedades indígenas existe uma intersecção do conceito espaço e tempo na organização da memória e da sociedade. Nas narrativas desse grupo, estão ausentes as informações cronológicas, como indicação de datas, anos, meses, semanas e dias, embora seja contínuo o uso de advérbios como "muito antigamente", "antigamente"; "agora" e "atualmente" para identificar períodos da história indígena anterior e posterior aos contatos e as mudanças desfavoráveis após esse acontecimento, como as expressões descritas no quadro abaixo:

Quadro 1: Expressões de tempo

\begin{tabular}{|c|c|}
\hline Expressão na Língua materna & Expressão na Língua portuguesa \\
\hline \multicolumn{2}{|c|}{ Povo Gavião } \\
\hline Man & Antigamente \\
\hline Ehntaacym & Agora \\
\hline \multicolumn{2}{|c|}{ Povo Karajá } \\
\hline Ehetxiu & Antigo \\
\hline Wiji & Hoje \\
\hline \multicolumn{2}{|c|}{ Povo Tapirapé } \\
\hline 'Ymywara & Antigamente \\
\hline Ygwâra & Agora \\
\hline \multicolumn{2}{|c|}{ Povo Xavante } \\
\hline Durei hã & Antigamente \\
\hline Durei hé & Até agora \\
\hline \multicolumn{2}{|c|}{ Povo Xerente } \\
\hline Ahâmre & Antigamente \\
\hline Tâkãinni & Atualmente \\
\hline
\end{tabular}

Fonte: autores.

Nas aulas do tema contextual Etnicidade e diversidade cultural, desenvolvido em janeiro de 2017 na etapa presencial na UFG, em uma das apresentações dos estudantes Xavante houve a menção ao termo "antigamente". Para o grupo, o termo remetia ao período anterior ao contato com os não indígenas, em que predominavam os conhecimentos baseados na observação da flora como determinantes para as plantações, por exemplo. Não se plantava fora dos períodos destinados a tal fim. Conhecimentos voltados para o calendário ocidental, organizado em meses e estações como outono e inverno, eram desconhecidos.

No segundo grupo, as narrativas escritas pelos estudantes abrangem uma diversidade temática muitas vezes vinculada à história de origem do povo narrado, uma experiência vivida pelo estudante ou até mesmo a sua percepção referente aos processos futuros que o envolvem, como a inquietação oriunda da gradativa influência da cultura ocidental 
em relação ao futuro dos povos indígenas. A seguir, listamos alguns dos títulos destas narrativas:

- A origem do povo A'uweuptabi José Messias Moridadze Tseredzabdi)

- Infância e atual (Brewy Djuassa Karajá)

- História vivida (Daniel Pereira de Sousa Pastana Yudja Juruna)

- Qual o papel do homem maduro? (Rômulo Tsereru'õ)

- História do território Inỹ (Fábio Tuilari Tapirapé)

- Tratamento Xavante (Nicodemos Terowe Tserewede)

Tais histórias, conforme indicação dos títulos acima, remontam à vida de determinado povo antes do contato com os não indígenas (Xavante) e os desdobramentos após esse contato (Guajajara, Kamayurá e Inỹ), trazendo em si a crescente preocupação dos povos originários à medida que o processo do capital e seus agentes (agropecuaristas, madeireiros e outros) avançam em áreas indígenas.

Antigamente a gente vivia bem, não tinha preocupações nenhuma. Hoje em dia estamos vivendo no meio de muitas preocupações, pois nos dias de hoje a cultura do branco está entrando muito na aldeia, isso está acabando com a nossa cultura. Antigamente, nós não tínhamos preocupações sobre a nossa floresta, nossos rios, nossas comidas. Hoje os brancos estão acabando com a nossa floresta, cercam nossos rios, os peixes podem desaparecer. Por isso no dia de hoje os anciões ficam muito preocupados sobre a cultura, pois, a cultura do branco está entrando fortemente na aldeia, dominando a cultura do povo, acreditando que no futuro a cultura vai acabar (Maurício Kamaiurá, jul. 2017).

Hoje em dia na aldeia o povo Iny vive no meio da preocupação porque a cultura não indígena está entrando fortemente na aldeia do povo Inỹ. Antigamente não tinha isso, vivia com própria cultura. Depois que o homem branco e a tecnologia entrou as coisas mudaram porque o próprio indígena pesca com não indígena e também os retireiros provocam as queimadas na terra indígena. Isso está afetando a vida da comunidade indígena do povo Inỹ. Antigamente não tinha lixo na aldeia (Fábio Tuilari Tapirapé, jul. 2017).

Evidentemente que as preocupações dos povos originários, aqui representados pelos Kamaiurá e pelos Inỹ, surgem em virtude das invasões dos brancos sobre suas terras, trazendo toda sorte de influências negativas como a diminuição da floresta e dos rios, fatores que influenciam diretamente na sobrevivência física e cultural dos 
indígenas. A invasão dos brancos representa a imposição do tempo do progresso e do desenvolvimento do capital sobre culturas e povos originários, visando suprimir epistemes que prescindem do tempo como fator de organização ontológica e epistemológica.

A expansão do capital conta ainda com instrumentos poderosos de imposição dos marcos temporais ocidentalizados, como o cristianismo e a escola, visto que o "tempo" é um conceito fundamental da colonialidade, no sentido de controlar e promover o avanço de uma visão da sociedade com base no progresso e no desenvolvimento (MIGNOLO, 2011, p. 161). No entanto, nem sempre esse progresso e desenvolvimento denotam uma perspectiva razoável. Para Brewy Djuassa Karajá, as instituições não indígenas como a escola, a religião (igreja), o futebol e a festa trouxeram transformações culturais negativas para o povo Karajá:

Na minha infância eu olhava e percebia que as coisas era tudo tranquilo e normal, achava que o povo Inỹ era tranquilo e normal, achava que o povo Iny estava prosseguindo em algo correto ou não. Parecia que o mundo do Inỹ estava fixo, saíam na canoa, com arco e flecha, a pé e voltavam com suas pescadas e caçadas.

Até eu e os meninos brincávamos na beira do rio, banhando com suas brincadeiras tradicionais.

A partir daí não sei como tudo mudou, as coisas atualmente é completamente diferente, não existe mais o banho da coletividade.

Muitas vezes o povo Inỹ recebe as coisas boas que não pertencem à cultura do Inỹ, isso enfraquece a força cultural do Inỹ.

Então meus filhos ou outros meninos deveriam aprender e conhecer através dos seus familiares, pai, mãe, ancião e na escola (Brewy D. Karajá, jul. 2017).

Na narrativa de Daniel Pereira de Sousa Pastana Yudja Juruna História vivida - ele apresenta a primeira vez que foi na cidade do não indígena para estudar e aprender com os não indígenas a ser "homem grande". A ocasião levou Daniel Juruna, aos treze anos de idade, a refletir sentado na beira do rio:

O sol aqui é o mesmo nosso

0 céu aqui é o mesmo nosso

O vento aqui é o mesmo nosso

O calor aqui é o mesmo nosso

Quem sabe podemos ser iguais?

Mas vejo que eles são diferentes, vejo que não têm aproximação uns dos outros e que em nossa aldeia todos somos parentes (jul. 2017).

Fica claro, na narrativa, a percepção da diferença cultural entre os Juruna e a sociedade ocidentalizada, uma diferença situada para além dos 
aspectos da natureza por estar alicerçada na episteme ocidental sobre o tempo e modos de relações sociais construídos ao longo dos séculos pelo pensamento civilizatório europeu. Não significa afirmar que os povos indígenas rejeitaram a episteme ocidental, pelo contrário, desde um posicionamento intercultural de resistência ontológica e negociação com a sociedade envolvente, eles puderam interagir com as categorias de tempo ocidentais sem prescindir de seus modos de percepção temporais, muito mais voltados para um tempo percebido e vivenciado a partir do lugar e do corpo.

É desde o lugar e o corpo que muitos indígenas vivenciam a estruturação de suas narrativas de origem e a passagem do tempo nos ciclos de vida, como no caso dos Javaé, cujo princípio fundamental para se pensar nessa categoria é o fluxo de substâncias corporais. Na cosmologia Javaé, o tempo não existia nas aldeias subterrâneas (berahatxi), um espaço fechado onde eles viviam antes de saírem para o mundo de fora (ahanaóbira) - a dimensão visível - por meio de aberturas existentes em diversos lugares ao longo da Ilha do Bananal (TO).

Com a saída para o mundo de fora, os Javaé "começaram a morrer, em razão das relações sexuais (exteriorização de energia vital), que eram inexistentes do mundo 'de dentro', abaixo do fundo das águas" (RODRIGUES, 1993, p. 135), ocorrendo

a passagem de um tempo em não havia relações sexuais entre as pessoas, para um tempo em que as pessoas passam a fundir fluidos corporais. Foi depois do casamento, do encontro entre homem e mulher, da aliança entre o pai das moças e dos homens de outra família, que o tempo teve início, pois a mulher começou a sangrar, e homens e mulheres passaram a liberar energia vital de seus corpos" (RODRIGUES, 1993, p. 62).

Partindo desse pressuposto (a vivência do tempo desde e no lugar a partir e com o corpo), elaboramos um quadro de advérbios de tempo e lugar para que os estudantes identificassem os termos que poderiam expressar, nas suas línguas maternas, categorias que denotassem marcos temporais ou lugares. Para isto, eles deveriam narrar oralmente suas histórias, apresentá-las na sala de aula e posteriormente redigi-las. Em todas essas etapas deveria ocorrer em primeiro lugar a narração oral de uma experiência na língua materna, seguida da escrita na língua portuguesa. A última etapa, portanto, seria a verificação da incidência de expressões com significados semelhantes nas narrativas elaboradas na língua materna e na língua portuguesa. Os dados foram compulsados nos Gráficos 1 e 2, a seguir: 
Gráfico 1: Ocorrência de advérbios de tempo nas narrativas

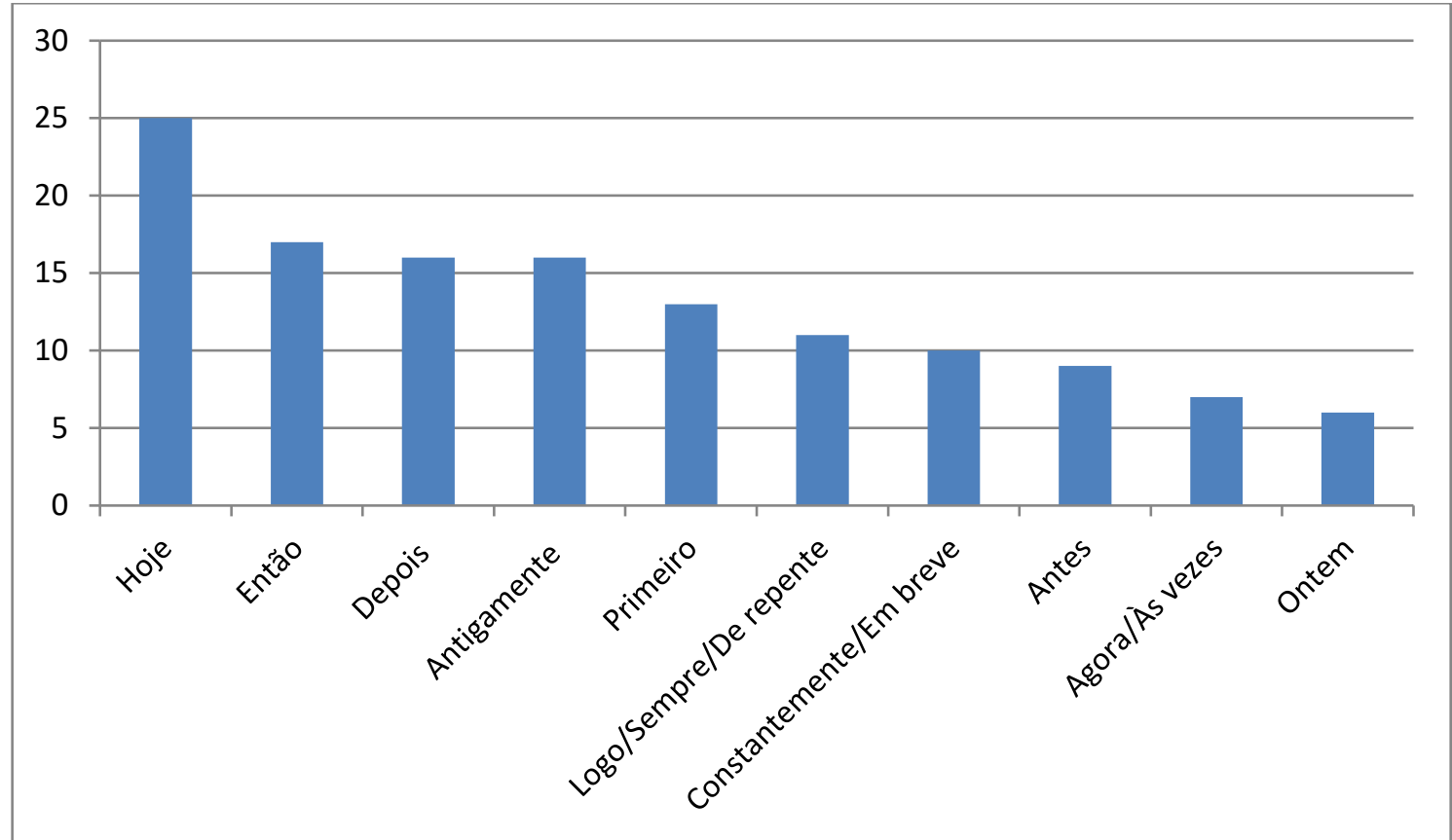

Fonte: elaborado pelos autores a partir das informações concedidas pelos estudantes.

Gráfico 2: Ocorrência de advérbios de lugar nas narrativas

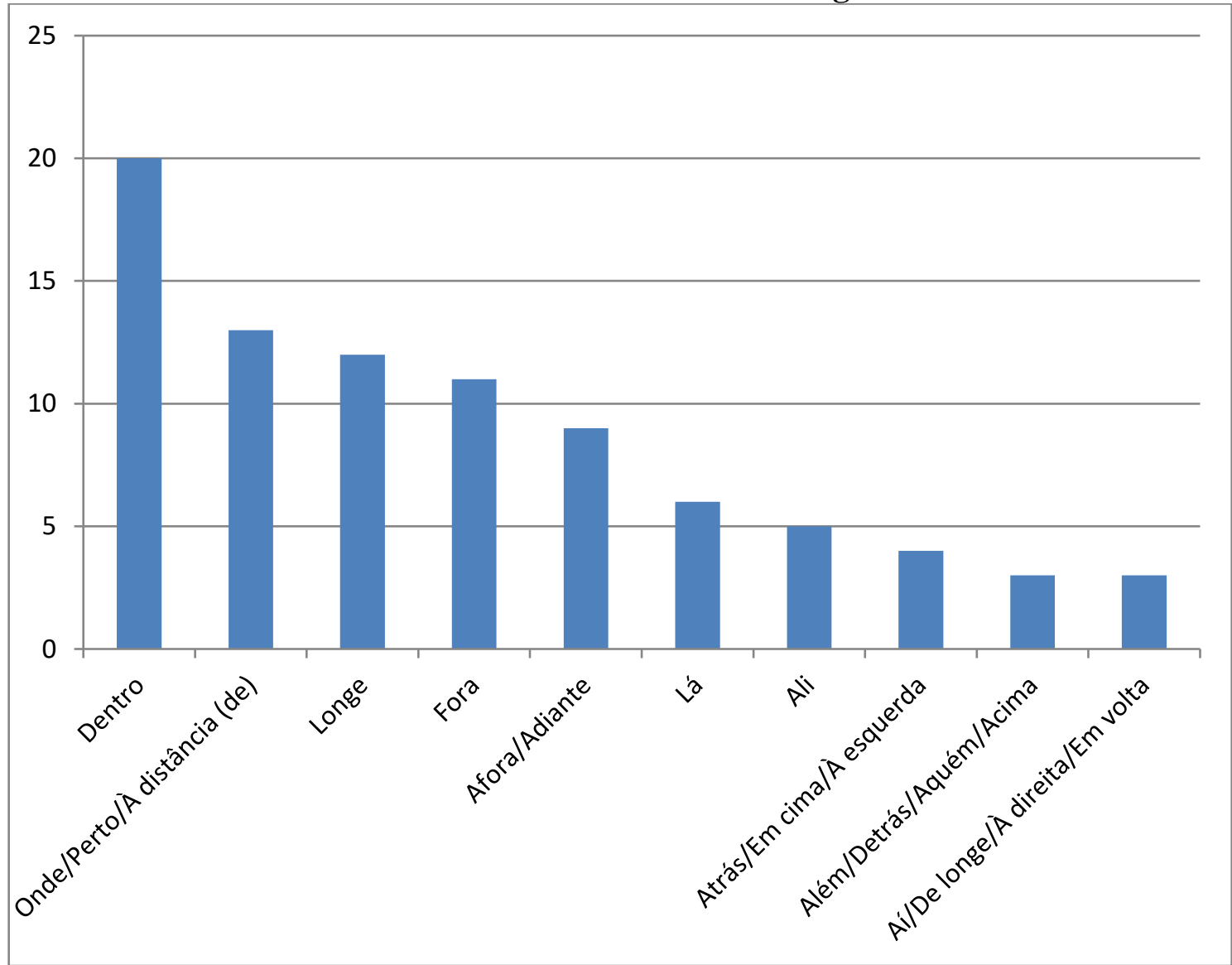

Fonte: elaborado pelos autores a partir das informações concedidas pelos estudantes. 
Embora haja a incidência de marcadores temporais em muitas narrativas elaboradas pelos estudantes indígenas, sinalizando para os processos interculturais ocorridos entre eles e a sociedade ocidental ao longo da história dos contatos, o advérbio de lugar mais indicado pelos estudantes foi "dentro", como sinônimo de pertencimento, de estar inserido num lugar e estabelecer sua identidade e saberes a partir dele. A resistência ontológica dos povos indígenas manifesta-se, desta maneira, apesar das tentativas de imposição de um padrão cultural pautado pela noção de tempo das sociedades ocidentalizadas que pendem para o progresso e o desenvolvimento e das exigências que a aceitação desta concepção acarreta para as pessoas, como é perceptível na narrativa a seguir:

Eu, Jair Krikati, nasci na aldeia São José, cresci na aldeia acompanhado de meus pais, de pesca, caça e outras atividades: corrida de tora e outros costumes tradicionais. Mas vindo o tempo do mundo comecei estudar ( $1^{\circ}$ a $4^{\circ}$ ano) na aldeia, mas não valorizei meu estudo, valorizei mais costumes (Jair Krikati, fev. 2017).

Ao narrar sua experiência, Jair Krikati afirma a necessidade de frequentar a escola em virtude de ter chegado o "tempo do mundo", embora ele mesmo não estivesse preparado naquele momento para isto, preferindo seus costumes. A retomada dos estudos aconteceu aos quinze anos, quando prosseguiu na sua trajetória escolarização até a inserção no ensino superior, tornando-se estudante do CEll.

Narrativas como estas e tantas outras apontam para a resistência ontológica indígena. Percebemos uma demanda em conhecer os códigos da escrita não indígena para um posicionamento político por parte dos estudantes, fator que reverbera na defesa de seus direitos e dos direitos de suas comunidades. Vale salientar que a educação na própria cultura é anterior ao percurso escolar, pois ocorre em todos os ambientes e em todos os momentos da vida cotidiana da aldeia: nos rituais, nas caçadas, nas pescas, nas florações, nas plantações, dentre outros. Buscar os processos de escolarização, nos moldes educacionais brasileiros, ocorre, na atualidade, após a alfabetização na língua materna.

Desta forma, a escola surge como um mecanismo intercultural de apropriação do saber para um fim: a negociação com a sociedade envolvente. Nestes termos, categorias e noções que visam impor determinado padrão cultural, como a própria noção de tempo ocidentalizada, são vivenciados, de modo intercultural, pelos diversos povos originários brasileiros. Evidentemente, processos de apropriação intercultural via escolarização na própria aldeia, como no caso citado dos Tapirapé, aponta para uma atualização cultural importante para a existência dos povos indígenas na contemporaneidade. 
De um direito constitucionalmente outorgado - a educação diferenciada -, tais povos passaram a buscar modos de atuação política e de luta por meio da formação de professores indígenas para atuarem em suas escolas desde e com metodologias próprias, pautadas pela retomada de cosmologias, conhecimentos e saberes da própria comunidade. Por isto, o uso de advérbios de tempo, tais como os indicados no Gráfico 1 , não evidencia processos assimilacionistas dos povos indígenas em detrimento de suas próprias experiências temporais ou espaciais; apenas aponta para as relações interculturais e a resistência ontológica estabelecidas ao longo da história colonizadora.

\section{Mapas existenciais}

Após o trabalho oral e escrito com as narrativas, propusemos como atividade didática o desenho de mapas existenciais, por considerá-los como as representações que mais se aproximariam da constituição identitária, de resistência e de afirmação dos estudantes que participaram do tema contextual Tempo, lugar e interculturalidade. Como atividade desenvolvida em grupo, configurou-se, a partir da participação deles, nove mapas existenciais dos povos indígenas Canela, Guajajara, Kamayurá, Karajá, Javaé, Tapuia, Xavante, Xavante e Xerente.

Nos mapas, os estudantes elaboraram, por meio de desenhos, seus territórios ancestrais, base à compreensão e experiência ontológica (enactiva) na qual se insere a relação com o mundo como espaço no qual eles estabelecem o existir, desde, com e a partir da corporeidade, incluindo a organização pautada pelas "estações" determinadas pela natureza. Uma existência que prescinde da concepção temporal construída e imposta pela episteme ocidental ao longo dos séculos. Assim, a identidade (ser) se faz desde uma percepção corporal da existência no mundo e das relações estabelecidas nos diversos espaços (lugares) vivenciados (visíveis e invisíveis), conforme pontuado a partir do enfoque enactivo.

As narrativas analisadas acima apontaram que, entre os povos indígenas, o calendário ocidental coexiste interculturalmente com o calendário ancestral. Enquanto a presença da escola institui um calendário oficial - ainda que ultimamente ele tenha sido reelaborado segundo os conhecimentos e saberes ancestrais em muitas aldeias indígenas - a resistência cultural de muitos povos perpetua um calendário ancestral, aquele que determina a ocorrência de atividades na aldeia (tempo de plantação, tempo de colheita, tempo de pesca, tempo de festa, tempo de caçada, tempo de cerimônias etc.) seguindo orientações dadas pelos fenômenos naturais, a saber: a incidência de fatores como teias de aranhas, raios solares, cantos de pássaros, ventos, posição dos astros (sol, lua e estrelas), florações e queda de folhagens, produção de frutas e outros alimentos, reprodução de peixes, aves e outros animais. 
A apresentação de Maurício Mattar Jakau Kamayura nos auxilia na percepção de como povos não ocidentalizados relacionam-se com o tempo. Em primeiro lugar, prescinde da separação cultura e natureza tendo em vista a existência de um calendário local pautado pelos sinais dados pelas estrelas que nascem no horizonte a leste e se põem a oeste, informando que a posição de uma estrela no céu determina o período para determinado acontecimento, por exemplo, o período de ausência de uma pessoa da aldeia, ou seja, o espaço de tempo entre a ida e a volta dessa pessoa. Observa-se, desta forma, uma marcação temporal definida em estações e não dias, semanas e meses, como o calendário ocidental.

Esta interligação entre os fenômenos da natureza e as atividades sociais e culturais dos Kamayurá, povo Tupi-Guarani da região do Alto Xingu no estado do Mato Grosso, corroboram para uma relação de complementaridade entre os fazeres cotidianos na aldeia - relacionados à sobrevivência física do povo ou à manutenção espiritual dos rituais e festas - e as determinações naturais, conforme observamos no desenho a seguir:

Figura 1: Mapa existencial Kamayurá

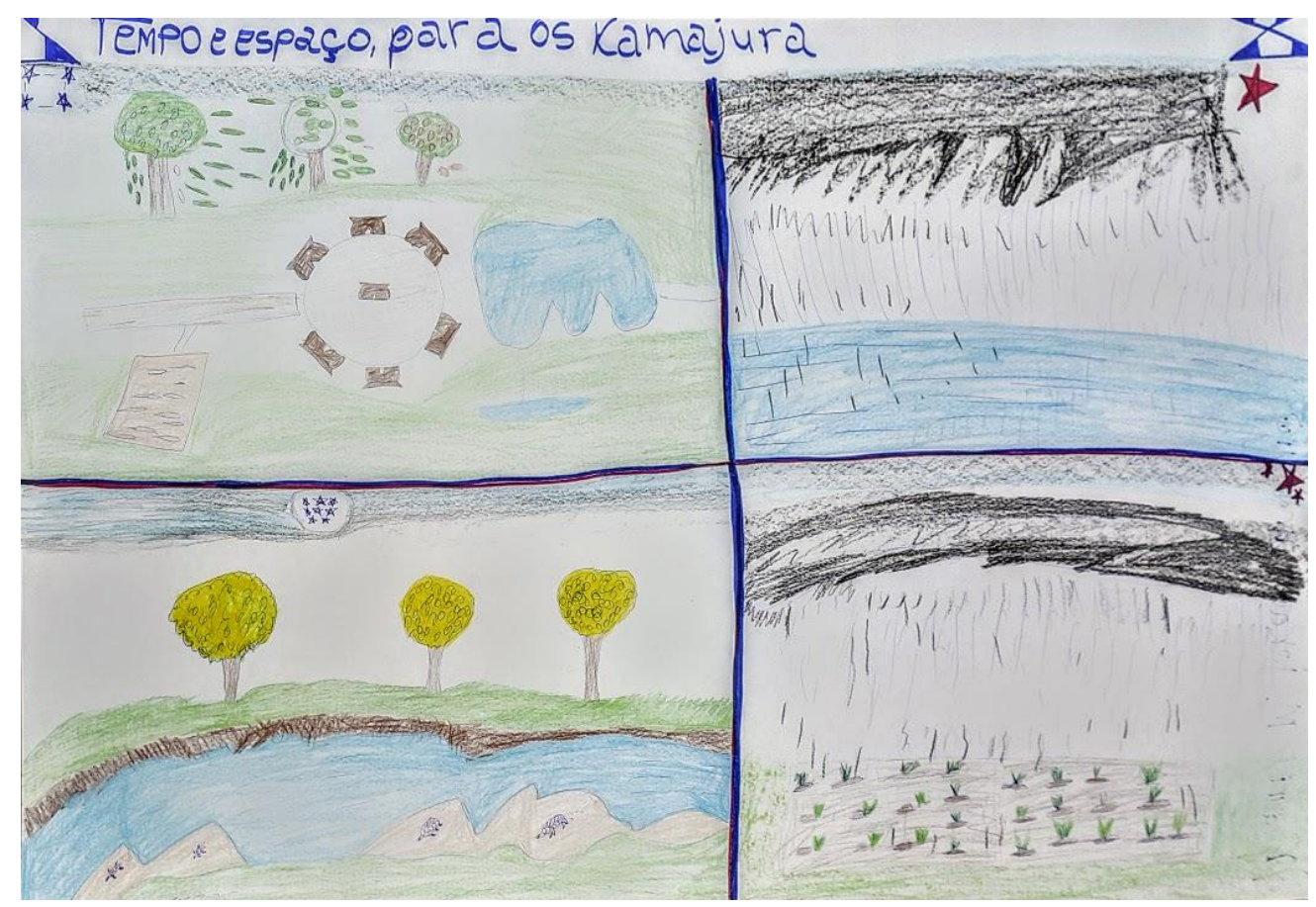

Fonte: acervo dos autores.

$\mathrm{Na}$ imagem observa-se uma representação do espaço de acordo com cada estação da natureza. O desenho divide-se em quatro partes, tendo em cada quadrante a representação de um período em sentido antihorário, determinado por uma estrela vigente. As quatro estrelas desenhadas são: Tukanan (por ter a forma de um jirau quadrado), Estrela d'Alva, Janupita (conhecida como Ema) e Atsingau. 
No primeiro quadrante, temos a representação da aldeia circular e alguns espaços próximos, como a lagoa sagrada, no lado direito. As folhas das árvores começam a cair por influência do surgimento da estrela Tukanan (no canto superior esquerdo), correspondendo aproximadamente ao mês de maio do calendário ocidental. Esse é o período final das chuvas e a chegada do "vento que vem para desfolhar as árvores", além de determinar o período de trabalho na roça e da produção de polvilho.

No centro do segundo quadrante, na parte superior, temos a Estrela d'Alva. Quando esta estrela atinge seu ponto mais elevado (a pino), sinaliza para a floração dos ipês e a ida dos tracajás rumo às praias para desovar, dentre outros fenômenos.

No canto superior direito do terceiro quadrante, Maurício Kamayurá desenhou a estrela Janupita, conhecida como estrela Ema. O surgimento dessa estrela traz consigo as primeiras chuvas, determinando o período do plantio seguido do crescimento da roça de mandioca. Por fim, no quarto quadrante, surge a estrela Atsingau que indica, dentre outros fenômenos, o meio das chuvas e a virada do ano. Geralmente, é avistada no período de janeiro a fevereiro.

De modo muito sucinto, Maurício Kamayurá compartilhou parte dos saberes e conhecimentos ancestrais de seu povo por meio do mapa existencial. Ainda que parcialmente, a representação acima possibilita perceber parte da cosmovisão dos Kamaiurá em relação aos processos temporais determinados pelos astros, seja com o surgimento das estrelas ou pelas fases da lua. São os astros que determinam o tempo do trabalho, das pescarias, da plantação, da colheita de mandioca, o tempo da seca, o retorno da chuva e tantos outros períodos de vivência do povo Kamaiurá, de acordo com o estudante.

De modo similar, a configuração territorial de Armando Prefete Kapelikó Kanela elenca no mapa existencial as estações anuais vivenciadas na aldeia. Porém, se diferencia da configuração anterior por representar o território em sua área total com especificidade para a aldeia Escalvado, no estado do Maranhão. Esta se constitui como a principal aldeia do povo Ramkokamekrá (Canela), povo de família linguística Jê e tronco Macro-jê, estando situada a aproximadamente $70 \mathrm{~km}$ da cidade maranhense Barra do Corda.

O território é ladeado pelo povoado Bacabal, pelo município de Fernando Falcão (MA) e pela cidade Barra do Corda, sul do norte maranhense. Armando Kanela representou os pontos cardeais por meio da rosa dos ventos e especificou o tempo de colheitas, o tempo de derrubada das matas, o tempo de queimada de coivara e o tempo de chuva. Além disso, ele desenhou os rios e as aldeias, o setor das roças, especialmente da aldeia velha e especificou, pela escrita, o local das frutas: 
Figura 2: Mapa existencial Canela

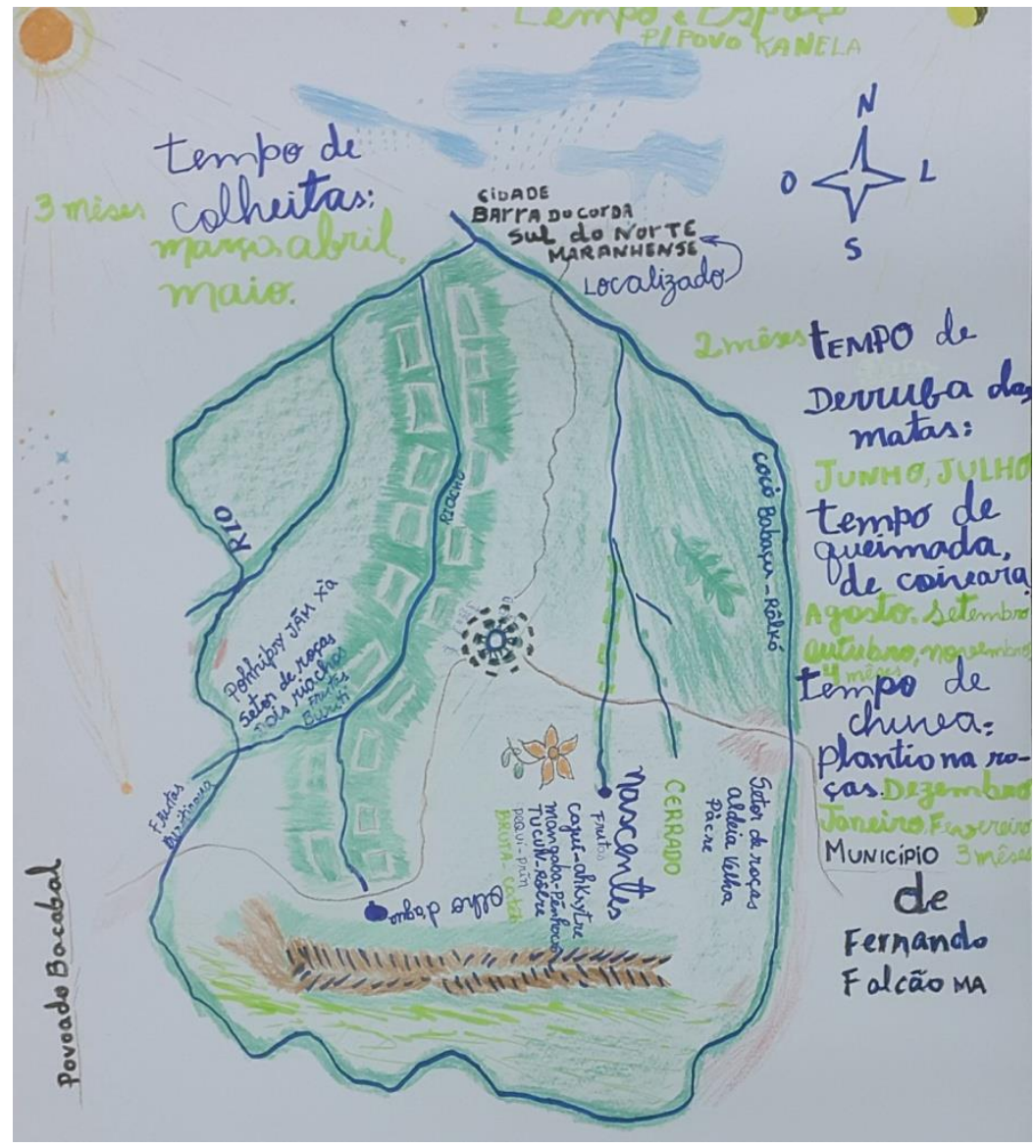

Fonte: acervo dos autores.

A partir do mapa existencial de Armando Kanela, delineamos os seguintes períodos que correspondem ao calendário anual do Ocidente:

Quadro 2: Calendário Canela

\begin{tabular}{|c|c|c|}
\hline Tempo de colheitas & Três meses & Março - maio \\
\hline $\begin{array}{c}\text { Tempo de derrubada das } \\
\text { matas }\end{array}$ & Dois meses & Junho- julho \\
\hline Tempo de queimada (coivara) & Quatro meses & Agosto - novembro \\
\hline $\begin{array}{c}\text { Tempo de chuva: plantio nas } \\
\text { roças }\end{array}$ & Três meses & Dezembro - fevereiro \\
\hline
\end{tabular}

Fonte: elaboração dos autores.

A seguir temos o mapa existencial karajá, povo Inỹ de família linguística Karajá, habitantes das margens do Rio Araguaia desde tempos imemoriais. Elaborado por Brewy Djuassa Karajá, Fábio Tuilari Tapirapé e Weretuma Karajá, nele os estudantes apresentaram o território com especificação de três aldeias. Uma delas é Hãwalò, com sua configuração 
de moradias e no pátio o campo de futebol. Conhecida como aldeia Santa Isabel do Morro, Hãwalò localiza-se à margem ocidental do Rio Araguaia, área de fronteira com o estado do Mato Grosso. As outras duas aldeias representadas são Itxala e Hawalora. Dentre as edificações destas últimas, sobressai em ambas uma "casa" distinta e maior que provavelmente representa a escola. Os rios Tapirapé e Berohoky (Araguaia), além de animais e áreas de mata e astros (sol e lua), foram igualmente representados neste mapa existencial.

Figura 3: Mapa existencial Karajá

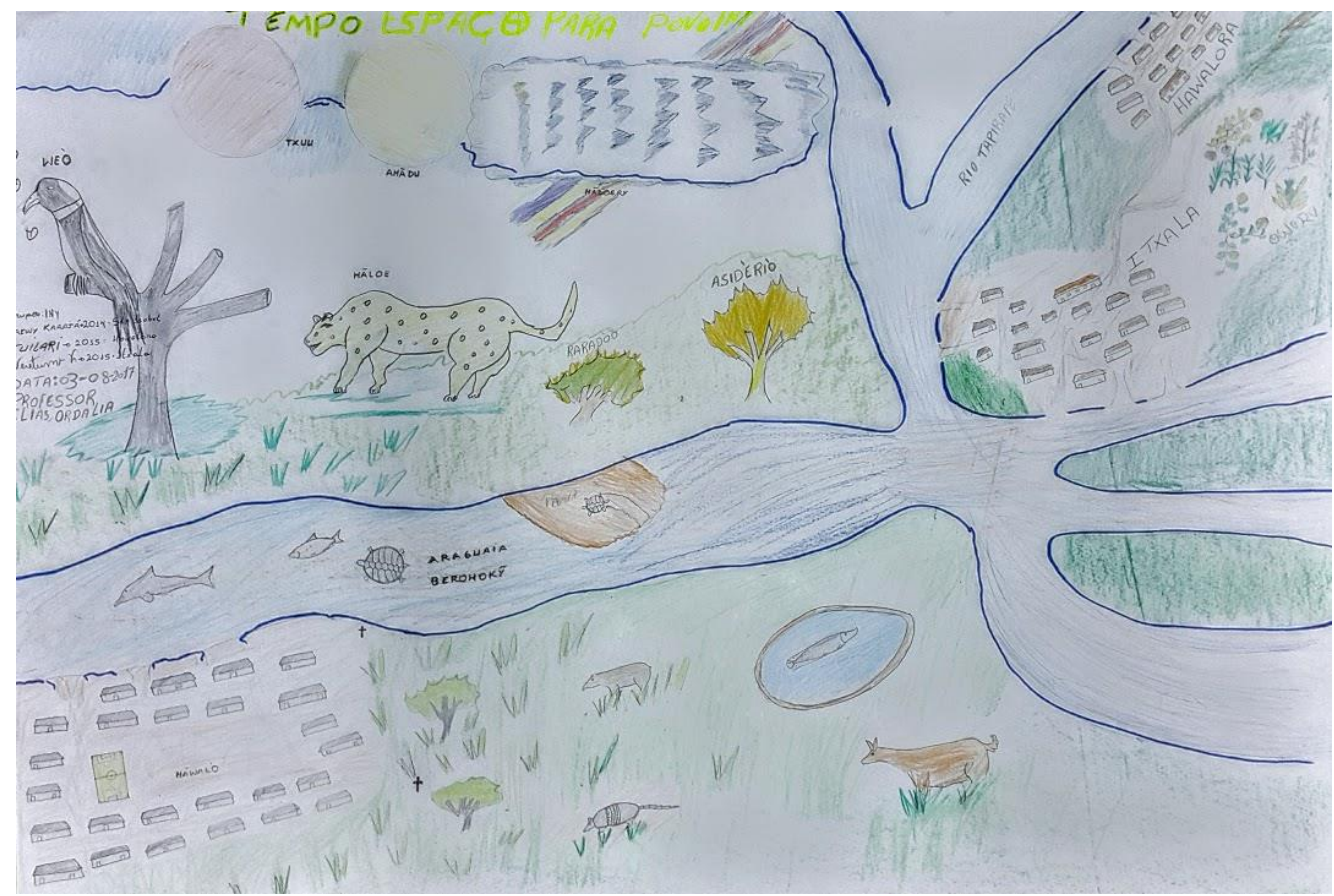

Fonte: acervo dos autores.

A representação da terra indígena na sua totalidade foi perceptível na maior parte dos mapas existenciais como um indício da intrínseca relação entre lugar e tempo nas cosmologias indígenas ainda na atualidade, como é possível observar nas figuras a seguir:

A primeira figura desenhada por Eliênia Caetano Martins representa o fragmentado território tapuia, situado na cidade de Rubiataba, estado de Goiás. Acima se encontra o cemitério e embaixo outro espaço, ambos separados da área maior por uma extensão de terra privada. As casas são de alvenaria e, próximo a elas, existe uma plantação comunitária. A segunda imagem, de autoria de Samanta Javaé, referencia a llha do Bananal, no estado do Tocantins, local de existência imemorial dos Inỹ, dentre eles, os Javaé. O destaque é dado para a aldeia Canoanã, situada na metade da llha, à margem direita do Rio Javaés, onde também se localiza o restante das aldeias alinhadas com o percurso fluvial. $O$ 
desenho destaca ainda, no interior da llha, a existência de lagos, sendo que o maior deles localiza-se próximo a um bananal, e áreas de floresta.

O mapa existencial acima, de autoria de Elivaldo Wakuke Xerente (aldeia Aparecida Nrõwdêhu), representa o território Xerente, no estado do Tocantins, constituído pela TI Xerente e pela TI Funil, com apoio da rosa dos ventos (pontos cardeais) e legenda na qual identifica a aldeia, a estrada para as aldeias, a rodovia, a mata fechada, o cemitério, o córrego ou ribeirão. A área limita-se com diversos municípios tocantinenses (Pedro Afonso, Tocantínia, Miracema, Rio do Sono e Aparecida). Os limites fluviais são dados pelos rios do Sono e Tocantins. Em todo o território, observa-se a representação de mais de sessenta aldeias, sendo quatro cemitérios representados na TI Funil com predominância da mata, nas áreas próximas às aldeias, e mata fechada na região mais distante.

Figura 4: Mapas existenciais Tapuia e Javaé

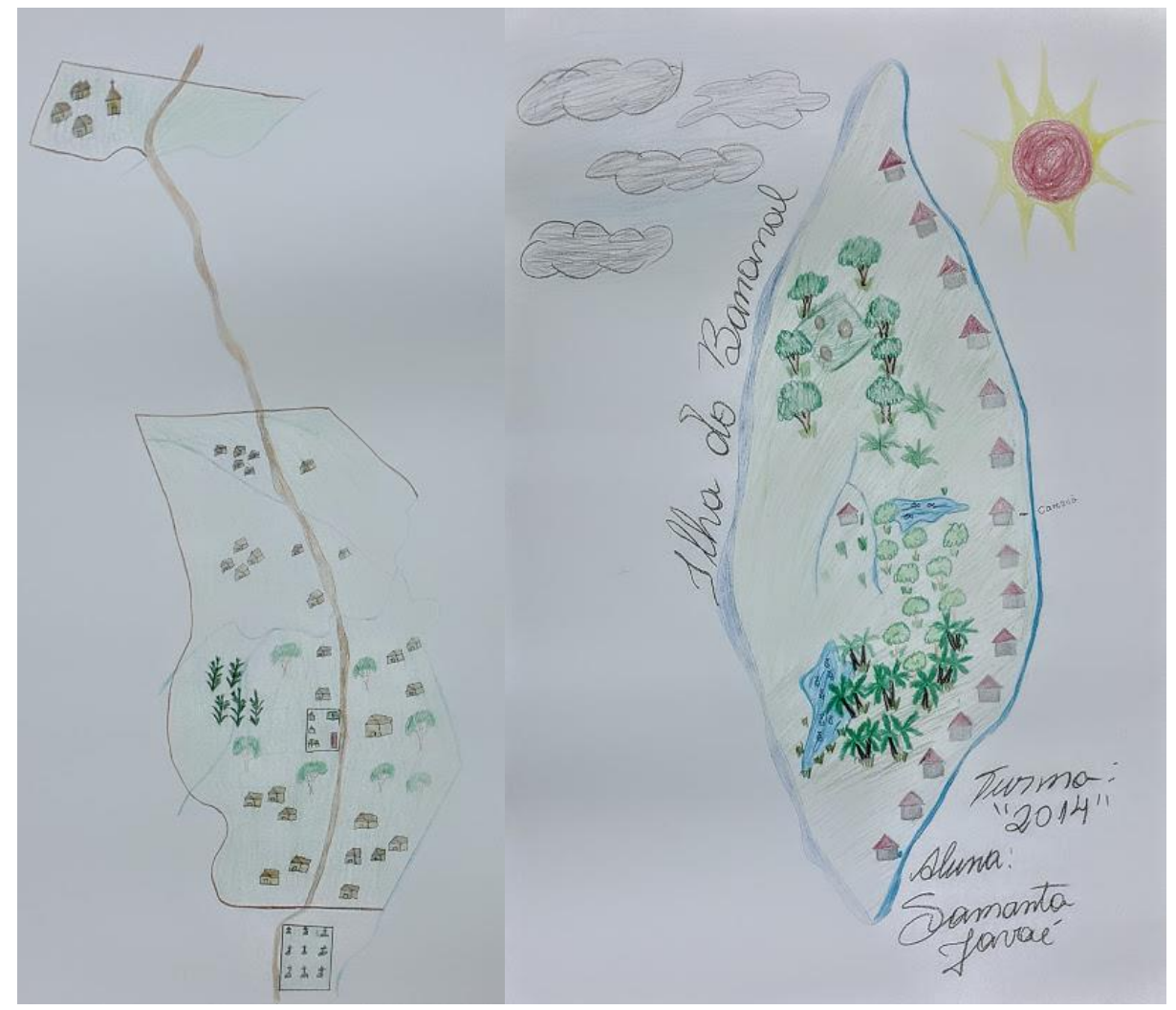

Fonte: acervo dos autores

Nas representações dos mapas existenciais, evidenciamos uma profunda interação com o espaço pelos povos indígenas participantes do tema contextual, perceptível por meio dos desenhos elaborados nos quais as representações cartográficas, espaciais e cosmológicas são ressaltadas por meio das representações minuciosas dos territórios indígenas na perspectiva macro (território em sua totalidade) ou micro, a partir da representação dos espaços de convívio cotidiano (a aldeia com 
suas subdivisões: locais sagrados, escola, igreja, posto de saúde, espaço de festas, de futebol, dentre outros).

Figura 5: Mapa existencial xerente

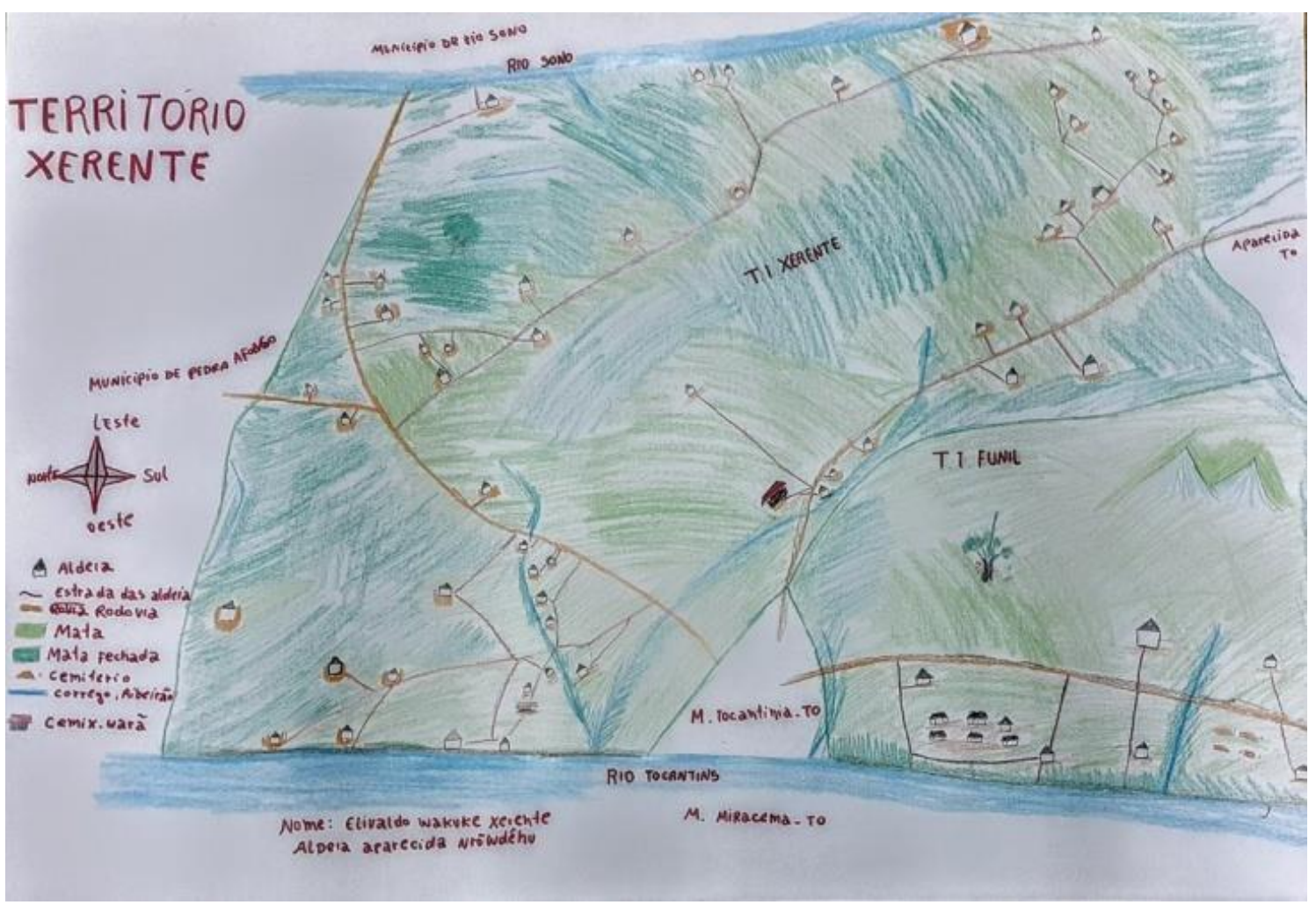

Fonte: acervo dos autores.

Desta forma, nos desenhos elaborados, os estudantes especificaram, além das aldeias, as áreas de roças nativas e mecanizadas, área de plantas medicinais, cemitérios, cerrados, matas fechadas e animais (seriema, gavião, coruja, tatu, onça), astros (sol, lua, estrelas), rios, córregos e lagos com seus peixes e tartarugas, ventos, chuvas, rodovias, pista de pouso, marcos delimitadores dos territórios indígenas, cidades fronteiriças, enfim, toda uma composição que nos leva a admitir a relação indissociável entre tempo, espaço, corpo e natureza conforme a perspectiva do enfoque enactivo, anteriormente citado.

\section{Considerações}

Em busca das estratégias de sobrevivência e de negociação com a sociedade envolvente, alguns povos indígenas viram-se diante da necessidade de ter que estudar em instituições de ensino externas ao território ancestral, construindo narrativas centradas em suas trajetórias de escolarização. Desse modo, construíram narrativas, por assim dizer, 
cronologizadas, marcadas por datas, períodos/séries, começo e fim, de linearidade e desenvolvimento. Muitas vezes, tais narrativas relacionamse à perspectiva de futuro e às demandas gestadas nas relações assimétricas produzidas entre indígenas e não indígenas ao longo da colonização, especialmente àquelas que dizem respeito à invasão territorial em virtude do avanço das relações capitalistas em muitas áreas indígenas.

Com as conquistas dos movimentos indígenas nas últimas décadas do século XX, especialmente a partir do marco constitucional de 1988, as escolas indígenas assumem características, ainda que em muitos casos limitadas, dialógicas e interculturais. De instituição promotora do assimilacionismo e integracionismo à cultura ocidental, a escola indígena passou a abrigar pessoas, culturas e saberes dos povos indígenas desocultando elementos da cultura ancestral em sua relação de interculturalidade com os conhecimentos ocidentais.

Assim, trazer à tona o debate em torno de noções como tempo e lugar revela a possibilidade de diferentes formas de apreensão e construção de narrativas históricas que se estruturam de diferentes formas. As histórias indígenas, com suas experiências locais e cotidianas, parecem confirmar esta possibilidade.

O espaço relaciona-se intimamente com a cultura de cada povo indígena e remete a temporalidades que, em alguns casos, prescindem da cronologização, ou seja, organizam-se em torno de orientações cosmológicas ao apresentar uma intrínseca relação entre tempo e lugar, uma relação na qual a natureza (rios, animais, plantas, astros, pessoas) integra e influencia a cultura, compondo uma totalidade que se caracteriza pela reciprocidade e dependência entre cultura e natureza, corpo e mente, teoria e prática.

\section{Referências bibliográficas}

CASTRO-GÓMEZ, Santiago. Lugares de la ilustración: discurso colonial y geopolíticas del conocimiento en el siglo de las luces. In: CASTRO-GÓMEZ, Santigo. La hybris del punto cero: ciencia, raza e ilustración en la Nueva Granada (1750-1816). 1a ed. Bogotá: Editorial Pontificia Universidad Javeriana, 2005. p. 20-64.

ELIAS, Norbert. Sobre o tempo. Rio de Janeiro: Zahar, 1998.

ESCOBAR, Arturo. Mundos y conocimientos de otro modo: el programa de investigación de modernidad/colonialidad latinoamericano. Tabula Rasa, Bogotá, n. 1, p. 51-86, jan.dez. 2003. 
O lugar da natureza e a natureza do lugar: globalização ou pósdesenvolvimento?. In: LANDER, Edgardo (org). A colonialidade do saber: eurocentrismo e ciências sociais: perspectivas latino-americanas. Argentina: CLACSO, 2005. p.133-168.

En el trasfondo de nuestra cultura: la tradición racionalista y el problema del dualismo ontológico. Tabula Rasa. Bogotá-Colombia, n. 18, p. 15-42, enero-junio, 2013.

LIMA, Sélvia Carneiro de; NAZARENO, Elias. Territórios ameaçados, saberes ressignificados: a cartografia social como possibilidade nas estratégias de luta dos Tapirapé. In: CABRERA, Olga (org.). Interdisciplinaridade e meio ambiente. São Luis: UFMA, 2014. p. 247-276.

MALDONADO-TORRES, Nelson. A topologia do ser e a geopolítica do conhecimento. Modernidade, império e colonialidade. In: SANTOS, B. V de S.; MENESES, M. P (Orgs.). Epistemologias do sul. Editora: Cortez: CES, 2010.

MIGNOLO, Walter. Histórias locais/projetos globais: colonialidade, saberes subalternos e pensamento liminar. Belo Horizonte: Editora UFMG, 2003.

Desobediencia epistémica: retórica de la modernidad, lógica de la colonialidad y gramática de la descolonialidade. Ediciones del Signo, Argentina, 2010. In: BLANCO, Juan. Cartografía del pensamento latinoamericano contemporáneo: una introducción. Cuadernos Winaq. Guatemala: Universidad Rafael Landívar. 2009/ p. 25-46. Disponível em: 〈http://biblio3.url.edu.gt/Publi/Libros/2013/Cartografia/01.pdf>. Acesso em 21 out. 2014.

. (De)Coloniality at Large: Time and the colonial difference. In: MIGNOLO, Walter. The darker side of western modernity: Global future, decolonial options. EUA: Duke University Press, 2011. p. 149-180.

NAZARENO, Elias. História, tempo e lugar entre o povo indígena Bero Biawa Mahãdu (Javaé): a partir da interculturalidade crítica, da decolonialidade e do enfoque enactivo. UNILA, no prelo, 2016.

Revisitando o debate acerca da modernidade a partir da colonialidade do poder e da decolonialidade. Revista Nós: Cultura, Estética e Linguagens, Goiás, v. 2, n. 2, p. 32-49, 2017.

NAZARENO, Elias; ARAÚJO, Ordália C.G. Reflexões em torno do tema contextual "Etnicidade e diversidade cultural". Revista Articulando e construindo saberes, Goiânia, v. 2, n. 1, p. 115-131, 2017. 
NAZARENO, Elias; CARDOSO, Ludimila Stival. Crítica do dualismo ontológico racionalista ocidental a partir da decolonialidade e da enación. Fragmentos de cultura, Goiânia, v. 23, n. 3, p. 245-254, jul./set. 2013.

NAZARENO, Elias; DIAS, L. O. (orgs.). Conhecimentos Indígenas na UFG: povo indígena Pyhcop Cati Ji - Gavião. Goiânia: Editora da Imprensa Universitária, 2017.

NAZARENO, Elias; RIBEIRO, J. P. M. (orgs.). Conhecimentos indígenas na UFG: povo indígena Berò Biawa Mahadu/Javaé - Volume IX. 01. Goiânia: Editora da Imprensa Universitária, 2017.

QUIJANO, Aníbal. "Colonialidad del poder, eurocentrismo y América Latina". In: LANDER, Edgardo (org.). La colonialidad del saber: eurocentrismo y ciências sociales. Perspectivas latinoamericanas. Buenos Aires: CLACSO/UNESCO, 2000.

RODRIGUES, Patrícia de Mendonça. O povo do meio: tempo, cosmo e gênero entre os Javaé da Ilha do Bananal. 1993. Dissertação (Mestrado em Antropologia). Programa de Pós-Graduação em Antropologia, Universidade de Brasília - UnB. Brasília, 1993.

SANTOS, B. V de S. A Gramática do tempo: para uma nova cultura política. Porto: Edições Afrontamento, 2006.

SILVA, L.; REZENDE, T. F.; NAZARENO, Elias; NASCIMENTO, A. M. (orgs.). Documentação de saberes indígenas na UFG. Goiânia: Gráfica UFG, 2017.

STEIL, Carlos Alberto; CARVALHO, Isabel Cristina de Moura. Epistemologias ecológicas: delimitando um conceito. Mana: Estudos de Antropologia Social, Rio de Janeiro, n. 20, v. 1, p. 163-183, 2014.

VARELA, Francisco J.; THOMPSON, Evan; ROSCH, Eleanor. De cuerpo presente: las ciencias cognitivas y la experiencia humana. Barcelona, Espanha: Editorial Gedisa S.A, 1992.

WALSH, Catherine; VIAÑA Jorge; TAPIA, Luis. Interculturalidad crítica y educación intercultural. Bolívia: Instituto Internacional de Integración, 2010.

WALSH, Catherine (org). Pedagogías decoloniales: prácticas insurgentes de resistir, (re)existir y (re)vivir. Tomo I. Quito: Ediciones Abya-Yala, 2013.

Recebido em: 11/01/2018 * Aprovado em: 14/09/2018* Publicado em: 27/06/2019 